\title{
ASSESSING COMPETENCIES OF TOURISM STUDENTS THROUGH POSTER PRESENTATION: EVIDENCE FROM INDONESIA
}

Ilham Junaid ${ }^{1}$

\author{
${ }^{\prime}$ Tourism Management Makassar Tourism Polytechnic Jl. Gunung Rinjani, \\ Kota Mandiri, Tanjung Bunga, Makassar, South Sulawesi-Indonesia \\ Email:illank77@yahoo.co.id Tel:+6285256995927
}

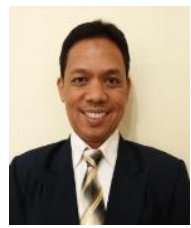

\section{ABSTRACT}

Article History

Received: 8 June 2018 Revised: 6 August 2018 Accepted: 10 September 2018 Published: 19 October 2018

Keywords

Poster presentation Competencies

Assessment

Tourism education

Indonesia

Tourism students

\begin{abstract}
This paper aims to examine the effectiveness of poster presentation in assessing the tourism students' competencies. Three issues were investigated including the students' responses, strengths and weaknesses and the students' recommendation for more practical students' learning. This research employed a case study approach (from July to December 2017) at Makassar Tourism Polytechnic, Indonesia. The study reveals that although students were worried about the implementation of poster presentation, the students were successfully participated in the examination through poster presentation. Three strengths were found including the students understand topics and sub-topics of a subject; link tourism concepts with the real context; and improve their self-confidence. This paper recommends the implementation of poster presentation for two reasons; 1) it supports the students to learn tourism concepts and issues independently; 2) it implements systematic ways including input (lecturer explains it), process (students prepare their poster), and output (students' competencies).
\end{abstract}

Contribution/Originality: The paper's primary contribution is finding that poster presentation has provided the opportunity for students to have intercultural competencies and sense of responsibility on environmental issues. Poster presentation is an option for teachers to assess the students' competencies. It enables students to create and present poster through critical thinking.

\section{INTRODUCTION}

Job employment provided by the tourism industry has encouraged members of community to choose tourism education as their future career including in Indonesia. The existence of the tourism industry in a destination has proved to be useful in creating and providing jobs for community in a destination (Hall et al., 2004; Wall and Mathieson, 2006; Wang et al., 2010).

The Indonesian government (through The Ministry of Tourism) has been supervising six high tourism educational institutions (Bali, Bandung, Makassar, Medan, Lombok and Palembang) to support the need of community on tourism education. The tourism education is expected to produce human resources that can meet the tourism industry's labor needs. It is the role of the tourism higher schools or universities to implement curriculum (programs and strategies) (Tribe, 2005) that can support the graduates to win the competition of employment at the tourism industry.

Skills, knowledge and attitude are always mentioned in the management of educational programs by the tourism higher schools. This is reflected in the curriculum of six tourism higher schools that are supervised by The 
Ministry of Tourism, Republic of Indonesia. Makassar Tourism Polytechnic for instance, has included skill, knowledge and attitude in the curriculum development. Fidgeon (2010) argues that tourism education is reflected on "courses, course philosophy, levels of study, subject content and teaching and learning strategies".

Although skills, knowledge and attitude become the foundations of the curriculum management, such aspects are often problematic. Knowledge and attitude for example, need to be integrated in the teaching and learning strategies. However, issues arise on how the lecturers should implement teaching and learning strategies in order to produce qualified students based on the required competences.

In addition to teaching and learning strategies, a lecturer or teacher staff should implement strategy, methods or ways to assess the students' competencies. Traditionally, examination by the lecturers for the students is implemented through questions and answer, presentation, and written and/oral test. However, innovation in teaching and learning as well as different methods in examination is required to improve the quality of students. Volgger and Pechlaner (2014) affirm that innovation in teaching and learning is essential in supporting the tourism and hospitality education to improve the graduates' competencies.

Innovation may vary depend on the context of tourism and hospitality education. It is argued that distinctive method in assessing the students' competence is essential to achieve the goal of teaching and learning in tourism education. This paper aims to examine the effectiveness of poster presentation in assessing the tourism students' competencies. Poster presentation was implemented by the author to the students of tourism management at Makassar Tourism Polytechnic, Indonesia. Poster presentation was implemented to enhance the students' competencies toward the lessons studied during one semester. Chang and Hsu (2010) argue that tourism and hospitality education should implement approaches or strategies that can bring the graduates into international standard. For this reason, poster presentation is well recognized as a technique that provides the chance for the presenters (students) to design poster in a creative thinking.

Poster presentation in international conference enables the listeners or readers to understand the presenter's point of view through poster provided with explanation. For Inui et al. (2006) it is important for lecturers to balance between vocational and academic lessons for students. Tourism students require the mastery of skills and knowledge and thus, the balance will help the graduates to fulfill the workforce (Cooper, 2002; Lewis, 2005; Lewis, 2006; Airey et al., 2014). Tourism high schools encourage their teacher staff to implement innovative teaching and learning strategies. Makassar Tourism Polytechnic in particular, enhances the teacher staff (lecturers) to help improve the learners' competence. It is argued that it is essential to investigate the effectiveness of the teacher's strategy on teaching and learning. This research is based on the argumentation that qualified graduates also depend on how the teachers implement strategies in teaching including ways to examine the students' competence. To achieve the aims of this research, three research questions guided the author in investigating the conduct of poster presentation as a method as follow:

1. What are the tourism students' responses on the implementation of poster presentation on the examination process?

2. What are the strengths and weaknesses of poster presentation in enhancing the quality of learning by the tourism students?

3. What are the students' recommendations to enhance the quality of learning through poster presentation?

\section{LITERATURE REVIEW}

\subsection{The Need for Competencies in Tourism Education: Toward the Research Framework}

One of the goals of tourism education is to produce human resources that can fulfill the need of the tourism industry. To achieve the goal, graduates of the hospitality and tourism education are expected to have competencies. Volgger and Pechlaner (2014) propose forms of competencies that are essential in achieving the requirements of the workplace including "intercultural competencies, competencies in social responsibility and 
environmental ethics, mastering future issues, and competencies in information and communication technology". Graduates should have an understanding and knowledge about social and environmental issues and are able to propose solutions for such issues.

This is particularly reflected in the workplace where their competencies help them work in different social situation. In addition, the mastery of communication and information technology is essential as most current jobs utilize skills of communication and information technology by the employees.

However, graduates of hospitality and tourism education are not solely in the tourism industry or businesses. Possible employments for the graduates are open in other sectors such as the government offices, related or nonrelated tourism companies, schools or universities (staff or teacher staff), and etc.. To fulfill the jobs, candidates are expected to master competencies based on the requirements of the jobs. Competencies as proposed by Volgger and Pechlaner (2014) are then essential in doing the jobs. It is argued that the graduates' competencies provide the opportunity for them to work in different sectors (both tourism and non-tourism sectors).

In order to succeed in study and to win competition of the employment after they graduate, students of the tourism higher schools need to have different profile (Sheldon and Fesenmaier, 2014). Different profile refers to the ability of the students to do different jobs. Future employment in the tourism and hospitality industry will consider qualified graduates in terms of competencies in doing jobs (Rok, 2011; Ladkin, 2014; Sheldon and Fesenmaier, 2014). Tourism higher schools in particular, are responsible for creating qualified graduates. For this reason, programs and activities implemented by the tourism higher schools are very important in encouraging qualified graduates.

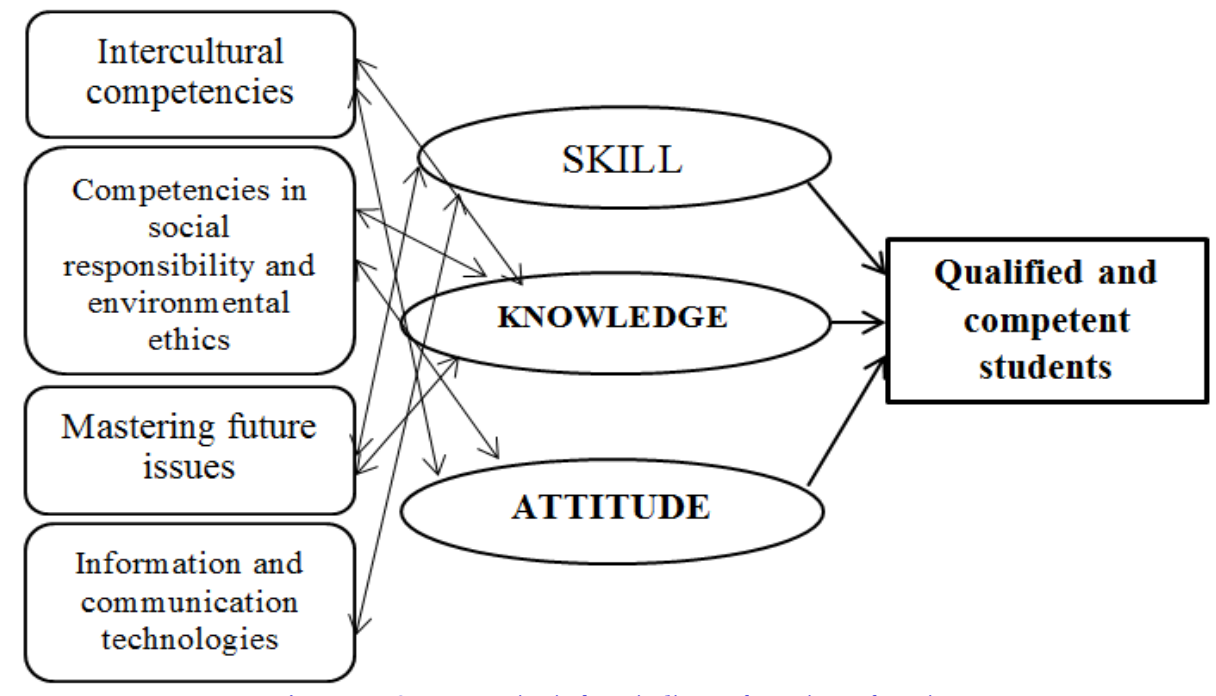

Figure-1. Competencies in hospitality and tourism education Source: Author, 2018 and adopted from Volgger and Pechlaner (2014)

For the purpose of the research, three kinds of competencies including skills, knowledge and attitude were used to examine the students' competencies. Skills refer to the ability of the students to make summaries of lessons through creating and/or choosing frameworks, short ideas, keywords, short sentences, and charts, in one poster. In other words, skills are the ability of the students to implement creative thinking without ignoring the importance of lessons that they have learned. Knowledge refers to the ability of the students to explain or present their understanding about concepts or lessons based on what they have made on the poster. In this sense, oral presentation enables the students to produce their knowledge. Attitude is the ability of the students to approach the lecturers, so the lecturers decide to provide their time for the students' presentation. To assess the students' competence of attitude is quite difficult. However, it is argued that the way the students communicate to influence the lecturers can be considered as a competence. In Indonesia, one's attitude can be shown on the way she or he 
communicates politely, appreciates people and behave accordingly. Skills, knowledge and attitude can be combined with the concept of Volgger and Pechlaner (2014) as shown on figure 1.

\subsection{Assessment and the Success of Teaching and Learning in Tourism Education}

The increasing numbers of research and the interest of many scholars in tourism education have enriched information about tourism education (Tribe, 2005). Tribe adds that various issues (either quantitative or qualitative) have been discussed among the researchers such as curriculum, teaching and learning, students' achievement, and resources in education. Such topics have enriched information about hospitality and tourism education. The information is then utilized by teachers, learners and educational institutions in implementing teaching and learning strategy for the purpose of achieving quality in education. The effects are then, on the teachers' quality of teaching, the learners' improvement of learning experience and the educational institutions' commitment in producing qualified human resources. In other words, research in tourism and hospitality is essential in providing useful information for the better conduct of teaching and learning.However, many issues in tourism education need to be researched to support more successful tourism education. Tribe (2005) argues that greater attention is required on methodological issues and the effectiveness of teaching and learning as well as how educational institutions implement effective assessment for the learners. In this sense, assessment method is one of important aspects in understanding the learners' competencies. It is argued that poster presentation is one of methods among many other forms of assessment to examine the students' progress. The reason for the implementation of poster presentation as a method for assessment is because higher educational institutions are expected to bring their graduates achieve their careers (Chang and Hsu, 2010). Teachers play major role in providing the opportunity for students understand concepts or theories of tourism and how they are used in the real context. The teaching role by the teachers is reflected on their knowledge or understanding about certain issues that others (learners) need to know through teaching and learning activities. Stergiou (2005) affirms that the teacher selects the content to be learned, adapts the material to the level of the students, helps the students to get access to the content, serves as a primary source of knowledge so that they become skilled at acquiring content. Participation by the students in the learning activities also affects the success of teaching and learning. Sheldon and Fesenmaier (2014) argue that learning objectives in tourism include the understanding of the learners about concepts, the ability of certain (tourism) skills, the development of new knowledge, the ability of questioning and answering, the ability of implementing creative efforts and the mastery of information and technology management. For this reason, different assessment implemented by teacher and is followed by the learner is essential in supporting the educational institutions produce competence graduates. Poster presentation is alternative method among the many methods that a teacher may implement in evaluating the teaching and learning.

\section{RESEARCH METHODOLOGY}

This research employed a case study approach with the emphasis on analyzing the implementation of poster presentation at Makassar Tourism Polytechnic. A case study approach enables the researcher to observe the environment of the case (Veal, 2006). A case study approach involves the role of the researcher in interpreting the data through the participants' voice. This research involves the students as the case participants as well as written documents by department of tourism management at Makassar Tourism Polytechnic. Three methods were utilized to collect information including observation, interviews and review the university documents (curriculum). The research was done from July to December (one semester). In particular, the author collected specific information in December 2017 when poster presentation was prepared and implemented by the first semester students of tourism management, Makassar Tourism Polytechnic. The subject for the poster presentation was 'geography of tourism'. This research was done based on four main steps as follow: 
1. The author taught the subject of tourism geography for one semester based on the syllabus of the subject (table 1). During the teaching and learning process, the author explained briefly about the last project (poster presentation) that the students must undertake as the requirement of the subject. Poster presentation was chosen as a method to examine the students' competence, a distinctive method that was chosen by the author to enhance the quality of learning.

2. In the beginning of December, the author reminded the students to prepare or design poster that would be used for presentation. The students were encouraged to include all the teaching and learning materials in one poster. To achieve this goal, the author assured that all teaching lessons were explained with examples during one semester.

3. Each student is required to choose a tourism attraction that is potentially discussed based on the topics in the subject of tourism geography. Natural tourism attraction (in Makassar or other areas in Indonesia) was encouraged as case study.

4. Students were then asked to design their poster in their own creative way.

5. Students presented their poster in the area of campus by inviting lecturers or the eighth semester students of tourism management. The role of the lecturers and the eight semester students was to assess the students' presentation. The author's role was to assess the students' presentation and to observe the conduct of the activity.

\section{DISCUSSION}

\subsection{Poster Presentation: Description and the Students' Responses}

Makassar Tourism Polytechnic establishes three departments including hospitality (diploma three of rooms division, food and beverage service, food production and diploma four of hotel administration); travel department (diploma three of tours and travel management, diploma four of travel business management and diploma four of event and convention management); and tourism department (diploma four of tourism management).

Table-1. Syllabus of tourism geography subject

\begin{tabular}{|c|c|c|c|c|}
\hline No & Weeks & Main topics & Sub-topics & Competencies (students are able to....) \\
\hline 1 & 1,2 & $\begin{array}{l}\text { Geography and } \\
\text { tourism }\end{array}$ & $\begin{array}{l}\text { - Geography } \\
\text { - Tourism } \\
\text { - Geography and tourism }\end{array}$ & $\begin{array}{l}\text { to understand and explain the definition of } \\
\text { tourism, geography and the relationship of } \\
\text { geography and tourism }\end{array}$ \\
\hline 2 & $3,4,5,6$ & $\begin{array}{lr}\text { Supply } & \text { and } \\
\text { demand } & \text { in } \\
\text { tourism } & \text { and } \\
\text { tourism } & \\
\text { resources } & \end{array}$ & $\begin{array}{l}\text { - } \\
\text { - } \text { Toupply and demand } \\
\text { - Classification and types of } \\
\text { tourism resources }\end{array}$ & $\begin{array}{l}\text { to understand and explain the concept of supply } \\
\text { and demand in tourism, classification and types of } \\
\text { tourism resources; to use the topics at tourism } \\
\text { attractions }\end{array}$ \\
\hline 3 & 7 & $\begin{array}{l}\text { Tourism } \\
\text { resources }\end{array}$ & $\begin{array}{l}\text { - The utilisation of tourism } \\
\text { resources } \\
\text { - } \begin{array}{l}\text { Benefits of tourism } \\
\text { resources }\end{array}\end{array}$ & $\begin{array}{l}\text { to understand and explain the utilization and the } \\
\text { benefits of tourism resources in the real context }\end{array}$ \\
\hline 4 & 8 & Mid-Semester Tes & & \\
\hline 5 & 9,10 & $\begin{array}{l}\text { Geographical } \\
\text { approach tourist } \\
\text { resort life cycle }\end{array}$ & $\begin{array}{l}\text { - Concept of tourist resort } \\
\text { life cycle } \\
\text { - The use of the concept in } \\
\text { the real life (tourism } \\
\text { attractions) }\end{array}$ & $\begin{array}{l}\text { to understand and explain the concept of tourist } \\
\text { resort life cycle and its utilization in the real } \\
\text { context }\end{array}$ \\
\hline 6 & 11,12 & $\begin{array}{l}\text { The impacts of } \\
\text { tourism }\end{array}$ & $\begin{array}{l}\text { - Impacts of tourism } \\
\text { (positive and negative) } \\
\text { - Evaluating and assessing } \\
\text { tourism impacts }\end{array}$ & $\begin{array}{l}\text { to understand and explain the impacts of tourism } \\
\text { both positive and negative and assess the tourism } \\
\text { impacts in a destination }\end{array}$ \\
\hline 7 & 13,14 & $\begin{array}{l}\text { Carrying } \\
\text { capacity } \\
\text { tourism }\end{array}$ & $\begin{array}{l}\text { - Carrying capacity of/in } \\
\text { tourism } \\
\text { - Types/kinds of carrying } \\
\text { capacity }\end{array}$ & $\begin{array}{l}\text { to understand and explain carrying capacity in } \\
\text { tourism, kinds of carrying capacity and use them in } \\
\text { the real context }\end{array}$ \\
\hline 8 & 15,16 & \multicolumn{3}{|c|}{ Final test (oral and written) } \\
\hline
\end{tabular}


Since the first establishment in 2010, tourism management is managed under the affiliation of Bali Tourism Institute.

Subjects are divided into vocational and non-vocational lessons. Most vocational subjects are managed based on the principle of theory and practice curriculum. This research examines the first semester students' competencies through the subject of tourism geography by implementing poster presentation. Eleven subjects are taught in the first semester including vocational subjects (introduction to tourism, introduction to hotel industry, introduction to travel service industry, basics of management, tourism geography, tourism anthropology, field study of tourism) and non-vocational subjects (general English 1, cross culture understanding, Pancasila (The Indonesian foundations), and religion). The teaching staff are guided by the teaching plan of semester (refers to syllabus), a brief description of teaching materials for one semester. There are fourteen weeks of teaching and learning (16 weeks in total), comprising seven weeks for theory and seven weeks for practice. For the subject of tourism geography, the teaching plan of semester can be seen on table 1.

When the author announced the method for last examination through poster presentation in December 2017, more students were worried whether or not they can do the assignment. Some students were not sure if they could follow this examination. Nevertheless, the author explained the poster presentation in a very specific way, assuring that the students understood how to make the poster. The following table (table 2) is summary of the author's observation during the process of the poster making as well as during the students' poster presentation:

Table-2. Summary of author's observation data

\begin{tabular}{|c|c|}
\hline Author's observation & Themes and issues on the observation \\
\hline Questions by the students & $\begin{array}{l}\text { - How to make schemes, figures or layout on the poster } \\
\text { - } \quad \text { Do I have to design poster by myself (students)? } \\
\text { - How about if I do not know computer programs? } \\
\text { - How to cover all the lessons in one poster? } \\
\text { - } \quad \text { Can I ask other people to design my poster? } \\
\text { - } \quad \text { How will hear or examine my poster presentation? } \\
\text { - } \quad \text { Why the eighth semester students were involved? }\end{array}$ \\
\hline Students' behavior & $\begin{array}{l}\text { - Worried on the way the author examined the students' } \\
\text { competencies. } \\
\text { - Not sure if they can do their best } \\
\text { - Not sure if they can make creative poster } \\
\text { - Not sure how to include all materials } \\
\text { - } \quad \text { Not sure if their poster is what the author expected }\end{array}$ \\
\hline Students' response & $\begin{array}{l}\text { - The students accept the examination method } \\
\text { - } \quad \text { The students were challenged to do the test } \\
\text { - } \quad \text { The students were happy to follow the activity }\end{array}$ \\
\hline
\end{tabular}

On the basis of interview to the students after the poster presentation, the author made summaries that represent the research findings as shown on table 3.

\subsection{Quality of Learning and the Students' Competencies: Toward the Strengths and Weaknesses}

The focus of tourism management program is the understanding of the students about issues in tourism and how they can propose practical solutions or strategies. Two interrelated aspects will affect the students' mastery including the quality of teaching and learning and the students' competencies. Although there are many factors that may affect the successful of teaching and learning (e.g. teacher, students, environment, facilities, etc.), strategies implemented by the teacher are essential in improving the students' learning quality and competencies. Poster 
presentation was designed to improve the quality and competence of the students. Nevertheless, as poster presentation was a new method for some students, the majority of students responded in a very different way. Questions arose from the students (table 2) indicate that the students were not sure how to prepare their presentation.

Table-3. Summary of qualitative information

\begin{tabular}{|c|c|}
\hline Themes/topics & Issues in data gathering \\
\hline Strengths of poster presentation & $\begin{array}{l}\text { - } \text { Eager to learn with many students } \\
\text { - } \quad \text { Improve students' self-confidence to speak in front of people } \\
\text { presentation and improve communicative competence through } \\
\text { - Understand and explain tourism attractions based on the } \\
\text { - } \begin{array}{l}\text { Able to deliver knowledge to others } \\
\text { - Understand how tourism attraction is managed and how to } \\
\text { develop it }\end{array}\end{array}$ \\
\hline $\begin{array}{l}\text { Things to improve for optimal result } \\
\text { learning }\end{array}$ & $\begin{array}{l}\text { - Maintain poster presentation program not only in } \\
\text { examination but also in other possible subjects or teaching and } \\
\text { learning activity } \\
\text { - Seeking lecturers or listeners for the students presentation } \\
\text { make difficulties in the program }\end{array}$ \\
\hline Expectations of the students & $\begin{array}{l}\text { - Examiners have been decided before the real presentation } \\
\text { - Students should create poster by themselves } \\
\text { - The importance of sustainability issues in the subject of } \\
\text { tourism geography }\end{array}$ \\
\hline
\end{tabular}

The majority of the students asked the author to explain poster presentation in a very specific way. To overcome this situation, the author gave examples on how to make diagrams or design; how to make useful simple sentences on a poster, how to choose keywords that may represent the lessons; what information/data should be included in the poster and how to present their poster. Many examples of poster are available on the internet or website. However, most examples are research results which then make students worried if they have to do a research. On the eight meeting of the teaching and learning, the author gave example of simple questionnaire that the students can use to gather information about the visitors' characteristics. This statistical information should also be included in the poster, and to obtain this data, the students must visit the tourism attraction and meet the visitors. The author then, encouraged the students to interview not less than fifteen visitors. Such numbers are less in statistical information, however, the data is used for learning how to analyse simple quantitative information.

Poster presentation has encouraged the students to improve their competencies of skill, knowledge and attitude. Skill is obtained through the students' efforts to create the poster. To create the poster, the students utilized computer software (such as Corel Draw, Microsoft Publisher and other related programs). Most students worked with colleagues, hoping that they can help each other particularly the use of computer programs. Besides, the students' skill is shown on their ability to make useful phrases, create diagrams, and create mapping for the tourism attraction. Knowledge is obtained through the students' efforts to understand the tourism concepts and how they are linked to social reality. The sub-topics of the subject are used to analyse current condition of the tourism attractions. Their knowledge is reflected on the ability to explain the topics and sub-topics as well as their ability to answer questions. 


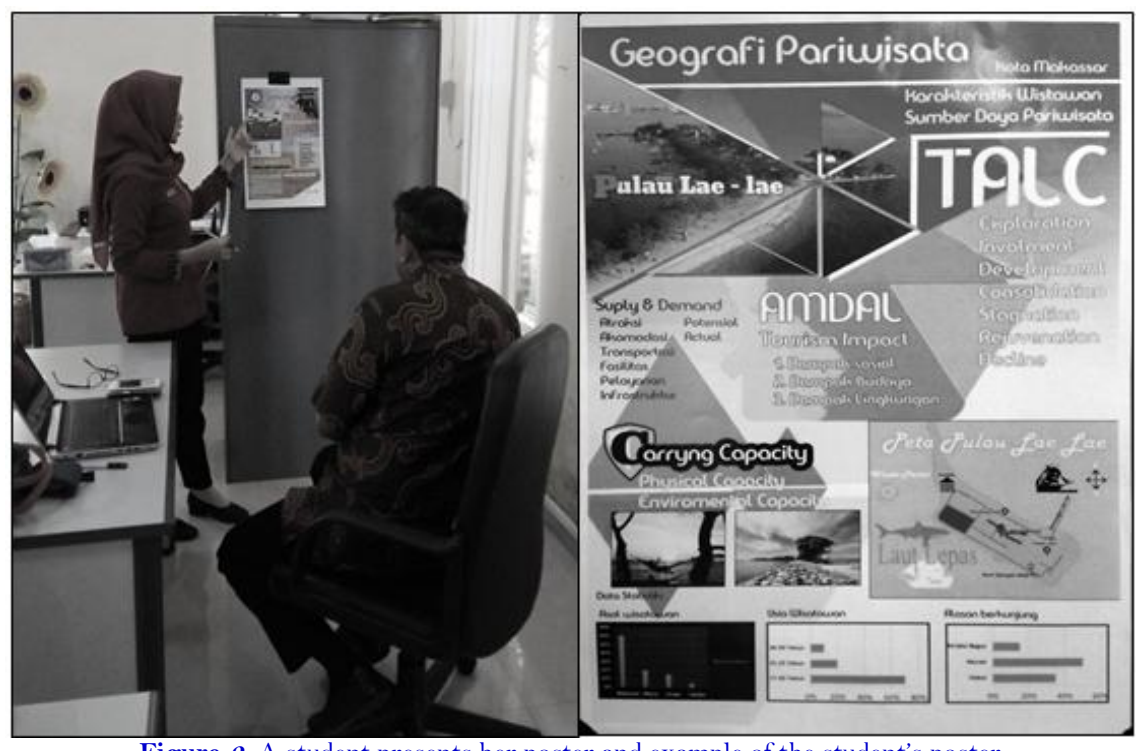

Source: Photo by author, 2017

Figure-2. A student presents her poster and example of the student's poster

Poster presentation enables the students to understand topics and sub-topics of a subject. Learning tourism geography should be supported with the real context. To write information about the topics and sub-topics on a poster and to explain the specific information, students should link the concepts with the tourism attraction. Poster presentation can only be done if the students have such information. In other words, topics and sub-topics of a subject should not only be taught on a conceptual basis. It is important for the students to visit the site, interview people, observe the tourism attraction and obtain relevant data. A student states "poster presentation provides the opportunity for us to understand Galesong Beach (a tourism attraction in Takalar regency of South Sulawesi province) based on the concepts learnt, to know how the beach is and should be managed and to recommend strategies for optimum management” (interview, December 2017).

Students should be able to deliver information to other people about the actual condition of a tourism attraction. Poster presentation is a learning strategy where students must present their data orally. A student states "poster presentation trains us to speak in front of people, we can invite or attract people to see our poster and presentation" (interview, December 2017). In other occasion, a student expresses, "through poster presentation, we learnt how to explain tourism attraction, we give knowledge to people about a tourism attraction, we explain tourism impacts, carrying capacity, the geography of a destination and attraction in one poster" (interview, December 2017).

Self-confidence by the students is essential for successful teaching and learning. Bosman and Dredge (2014) argue that students' competencies can be achieved by empowering and improving their communicative competence, critical thinking and ability to propose solutions on various problems. Poster presentation is an effort to develop the students' competence as mentioned by a student “poster presentation encourages me to present my own poster, by explaining my poster, I can increase my self-confidence, I can imagine that If I am on the higher (next) semesters, I am ready to do any assignments related to tourism topics" (interview, December 2017). It is argued that poster presentation helps the students to be a creative person in terms of implementing learning strategy. It is a strategy to improve the quality of learning. 
Table-4. Guidelines for the examiner in assessing the students' competence.

\section{Examination form, subject of tourism geography}

Name

Class

Examiner

\begin{tabular}{l|l|l}
\hline No & Assesment & $\begin{array}{l}\text { Score: }(\mathbf{1}=\text { Poor, } 2=\text { Fair, } 3= \\
\text { Good, } \mathbf{4}=\text { Very Good }\end{array}$ \\
\hline 1 & Mastery of concepts (lessons) & \\
\hline 2 & Presentation of poster and the ability of argumentation & \\
\hline 3 & Poster (Content and the ability of reader to understand) & \\
\hline & Total & \\
\hline
\end{tabular}

Signed by examiner,

In the implementation of poster presentation, the author requested the eighth semester students and lecturers to provide their time listen to the students' presentation (as examiners). For more challenge activities, the examiners may ask questions to students or request the students to explain topics in English. In fact, students felt that such strategy is not effective as they have to struggle to approach the lecturers. Problems may occur if they cannot find lecturers whilst the duration of the program is four hours. A student states "finding lecturers or examiners for our presentation seems to be difficult effort for us because some lecturers are not available, it is good if we don't have to find examiners by ourselves" (interview, December 2017). The examiners' request is a challenge for most students and thus, they have to accept and work hard for best result of presentation. Table 4 is guidelines for the examiner in assessing the students' competence.

Besides, students consider that the author should instruct the students to do their own poster. To some extent, allowing other people (designer or software designer) to do the poster does not support the students' hard working. Students believe that some students requested other people to do their poster as mentioned by a student "many people can make creative design, maybe some students are dishonest by requesting design experts to do the poster" (interview, December 2017). Indeed, the author does not emphasize the ability of the students to master software through poster making. However, for students, it is important to assure that each individual should learn programs for their individual computer skill.

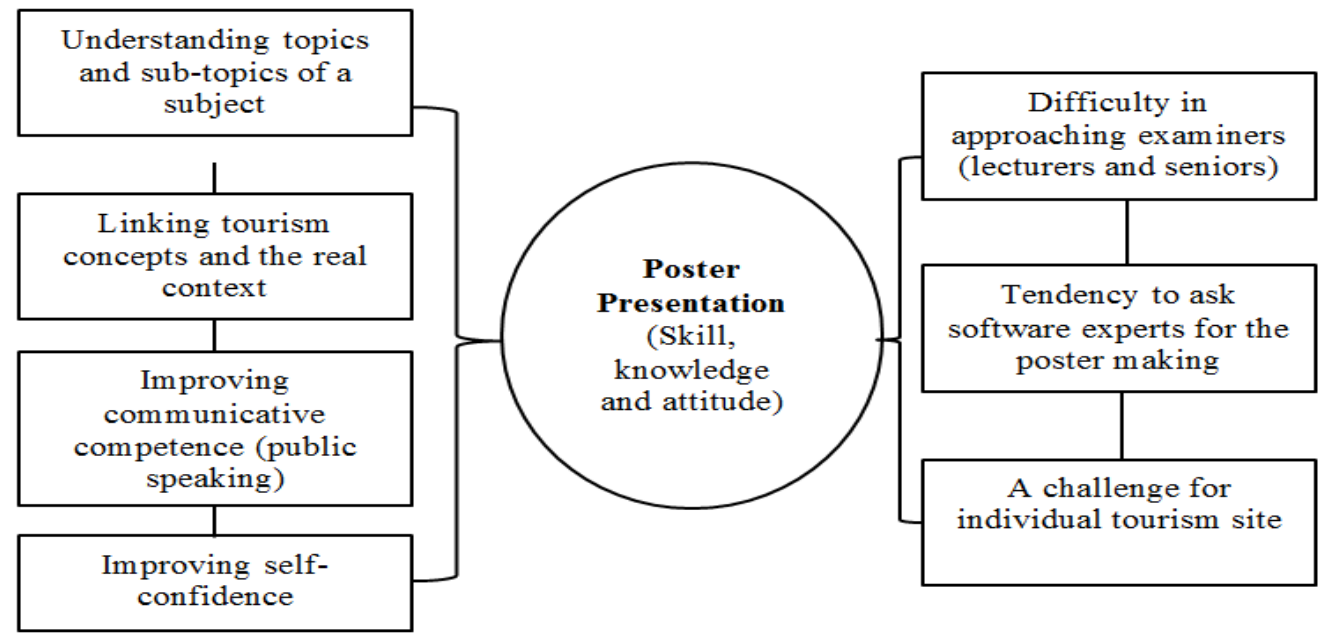
Source: Author, 2018

Figure-3. Strengths and weaknesses of poster presentation as a method for assessing the students' competencies 
In Indonesia, it is important to obtain consent from parents if students should visit tourism attraction without their teachers or instructors particularly female students. Since poster presentation requires real data of tourism attraction, some students felt that individual site visit without parents' consent is a challenge. Hence, they have to convince parents about the assignment. In Indonesian culture, obeying parents' instruction is a must, and thus, such attitude is a competence. Poster presentation has challenged the students to work individually and responsibly. As a method or strategy of examining the students' competencies, poster presentation has strengths and weaknesses. Figure 3 is a summary of strengths and weaknesses of poster presentation as a method.

\subsection{Suggestions for More Practical Tourism Students' Learning Activities}

Students require various activities in learning. Most students argue that poster presentation is a creative effort because they have to struggle to achieve the goals of poster presentation. Students must prepare their poster and present it individually. It is argued that individual learning is one of the benefits of poster presentation. Poster presentation is considered a method for examining the students' competencies because of three reasons. First, it supports the students to learn tourism independently. Second, it implements systematic ways including input (lecturer explains it), process (students learn and prepare their poster), and output (poster presentation enables the students to produce quality of learning in terms of their competencies). In other words, poster presentation is applicative and creative learning strategy that tourism and hospitality institutions may implement.

However, although positive comments were expressed by the students, suggestions for more practical and useful activities were mentioned. First, the students should not seek the lecturers or seniors to examine their presentation. During the day of the presentation, students struggled to find examiners as instructed by the author. For students, this is not the best way as many lecturers were not ready to hear the students' presentation. Ideally, examiners should be available anytime and they could be approached easily. The author's purpose is to provide the opportunity for students to improve their communicative competence through their ability to approach other people (competence of attitude). Nevertheless, the goal might not be achieved because of limited time and the difficulty to find the examiners. Hence, this paper argues that poster presentation will be useful if there is a mechanism that can help the lecturer in assessing the students' competence through poster presentation.

Second, examining the students' competence requires competitive efforts among the students. For some students, it is good to compete with others to convince the examiners through their presentation. In this sense, they are motivated to work hard because first, they have to struggle to finish the presentation; and second, they want to gain good score from the examiners. Motivation is an important factor in encouraging the students to learn tourism (Sigala, 2002; Su, 2014; Min et al., 2016) and thus, they have to be equipped with the ability to improve their competence through motivational approach. Poster presentation emphasizes the understanding of theories or concepts related to tourism and their link to real life. It is essential to develop the students' skills and technical competencies (knowledge and practicality) through creative strategy and motivational activities.

Third, it is essential to include sustainable or sustainable tourism education with the topics of tourism geography. According to teaching and learning syllabus of tourism geography subject, sustainable tourism is not mentioned. Moreover, there is no subject of sustainable tourism in the curriculum of Diploma four Tourism Management. Rather, sustainable tourism is included in other subjects. Sustainable tourism should be introduced at the beginning of the students' learning process so they understand how to preserve the planet. Individuals (particularly tourism students) should be encouraged to have knowledge about the importance of protecting environment through the concept of sustainability or sustainable tourism (Busby, 2003; Jennings et al., 2010; Canziani et al., 2012; Deale and Barber, 2012). In the implementation phase, the lecturer may link each topic of the tourism geography to sustainable issues or sustainable tourism development. For instance, when discussing about tourism impacts, the lecturer can support the lesson with issues of sustainability or sustainable tourism. 
Fourth, mastering technology is a competence that tourism students must have. Indeed, students can ask expert of computer software (e.g. Corel draw program) to create their poster. A student comments on how important computer mastery in designing poster for presentation. He believes that many students did not create their poster and for this reason, the author (lecturer) should ask the students to design poster individually. One of the targets of tourism education (tourism management) is the ability of the graduates in managing tourism destination through the utilisation of information and technology. Borzyszkowski (2014) and Leung et al. (2012) affirm that information technologies in tourism become tools in managing tourism organisations. To achieve the goals, tourism higher schools should prioritize the mastery of technology by their students so they can implement their competencies in the real workplace.

\section{CONCLUSION}

The increasing numbers of tourism higher schools and the establishment of tourism management by the university at different levels in the world and Indonesia in particular, indicate that tourism education has been accepted as an option for future career. Tourism educational institutions have major role in producing qualified human resources in tourism. Tourism higher schools consider that tourism graduates should have competencies of skill, knowledge and attitude and hence, they need to implement curriculum that can fulfill the needs of the tourism industry. For the purpose of human resource development, poster presentation is an option for teachers to assess the students' competencies. Through poster presentation, students learn how to create poster through critical thinking and the use of computer software. Students also learn tourism concepts (topics and sub-topics) and their implementation on the social reality. This paper has provided insights on how educational institutions can implement assessment method for qualified human resources.

The focus of tourism management program is the understanding of the students about issues in tourism and how they can propose practical solutions or strategies. Poster presentation has provided the opportunity for students to have intercultural competencies and sense of responsibility on environmental issues. The teacher can assess the students' competencies through poster presentation because it has three processes including input, process and output. This paper proposes four aspects that need to be considered in optimizing the quality of learning by the students through poster presentation including 1) students prefer not to seeking the examiners during the poster presentation; 2) poster presentation should be conducted with other students for more challenge activities; 3) the importance of sustainability issues or sustainable tourism in the subjects of tourism; and 4) the importance of mastering or utilizing computer software by the students rather than asking computer programmer to design the poster.

Funding: This study received no specific financial support.

Competing Interests: The author declares that there are no conflicts of interests regarding the publication of this paper.

\section{REFERENCES}

Airey, D., D. Dredge and M.J. Gross, 2014. Employment and career development in tourism and hospitality education. In D. Dredge, D. Airey \& M. J. Gross (Eds.), The Routledge Handbook of Tourism and Hospitality Education. London: Routledge. pp: 3-14.

Borzyszkowski, J., 2014. Information technologies in the activities of destination management organizations. Tourism and Hospitality Management, 2O(1): 61-70.

Bosman, C. and D. Dredge, 2014. Teaching about tourism in a post-disciplinary planning context. In D. Dredge, D. Airey \& M. J. Gross (Eds.), The Routledge Handbook of Tourism and Hospitality Education. London: Routledge. pp: $395-407$.

Busby, G., 2003. The concept of sustainable tourism within the higher education curriculum: A British case study. Journal of Hospitality, Leisure, Sport and Tourism Education, 2(2): 48-58. Available at: https://doi.org/10.3794/johlste.22.57. 
Canziani, F.B., S. Sönmez, Y. Hsieh and E.T. Byrd, 2012. A learning theory framework for sustainability education in tourism. Journal of Teaching in Travel \& Tourism, 12(1): 3-20. Available at: https://doi.org/10.1080/15313220.2012.650052.

Chang, T. and J. Hsu, 2010. Development framework for tourism and hospitality in higher vocational education in Taiwan. Journal of Hospitality, Leisure, Sport and Tourism Education, 9(1): 101-109. Available at: https://doi.org/10.3794/johlste.91.246.

Cooper, C., 2002. Curriculum planning for tourism education: From theory to practice. Journal of Teaching in Travel \& Tourism, 2(1): 19-39. Available at: https://doi.org/10.1300/j172v02no1_02.

Deale, C.S. and N. Barber, 2012. How important is sustainability education to hospitality programs? Journal of Teaching in Travel \& Tourism, 12(2): 165-187. Available at: https://doi.org/10.1080/15313220.2012.678211.

Fidgeon, P.R., 2010. Tourism education and curriculum design: A time for consolidation and review? Tourism Management, 31(6): 699-723. Available at: https://doi.org/10.1016/j.tourman.2010.05.019.

Hall, C.M., A.M. Williams and A.A. Lew, 2004. Tourism, institutions and issues. In A.A. Lew, C.M Hall, \& A.M. Williams (Eds.), A companion to tourism. Malden: Blackwell. pp: 235- 245

Inui, Y., D. Wheeler and S. Lankford, 2006. Rethinking tourism education: What should schools teach. Journal of Hospitality, Leisure, Sport and Tourism Education, 5(2): 25-35. Available at: https://doi.org/10.3794/johlste.52.122.

Jennings, G., S. Kensbock and U. Kachel, 2010. Enhancing 'education about and for sustainability'in a tourism studies enterprise management course: An action research approach. Journal of Teaching in Travel \& Tourism, 10(2): 163-191. Available at: https://doi.org/10.1080/15313221003792019.

Ladkin, A., 2014. Employment and career development in tourism and hospitality education. In D. Dredge, D. Airey \& M. J. Gross (Eds.), The Routledge Handbook of Tourism and Hospitality Education. London: Routledge. pp: 395-407.

Leung, D.H., A. Lee and R. Law, 2012. Examining hotel managers' acceptance of web 2.0 in website development: A case study of hotels in Hong Kong. In M. Sigala, E. Christou and U. Gretzel (Eds.), Social media in travel, tourism and hospitality: Theory, practice and cases. Burlington: Ashgate. pp: 73-86.

Lewis, A., 2005. Rationalising a tourism curriculum for sustainable tourism development in small Island States: A stakeholder perspective. Journal of Hospitality, Leisure, Sport and Tourism Education, 4(2): 4-15. Available at: https://doi.org/10.3794/johlste.42.93.

Lewis, A., 2006. Stakeholder informed tourism education: Voices from the Caribbean. Journal of Hospitality, Leisure, Sport and Tourism Education, 5(2): 14-24. Available at: https://doi.org/10.3794/johlste.52.120.

Min, J., H.-W.V. Tang and C.A. Chen, 2016. Ranking the personal excellence training needs of undergraduate tourism students. Journal of Tourism Management Research, 3(2): 37-46. Available at: https://doi.org/10.18488/journal.31/2016.3.2/31.2.37.46.

Rok, M., 2011. Stress and stress management in a higher education tourism institution. Tourism and Hospitality Management, $17(2): 279-290$.

Sheldon, P.J. and D.R. Fesenmaier, 2014. Tourism education futures initiative: Current and future curriculum influences. In D. Dredge, D. Airey \& M. J. Gross (Eds.), The Routledge Handbook of Tourism and Hospitality Education. London: Routledge. pp: 155-170.

Sigala, M., 2002. The evolution of internet pedagogy: Benefits for tourism and hospitality education. Journal of Hospitality, Leisure, Sport and Tourism Education, 1(2): 29-45.

Stergiou, D., 2005. Teaching. In D. Airey and J. Tribe (Eds.), An International Handbook of Tourism Education. Oxford: Elsevier. pp: 285-298.

Su, Y., 2014. Lifelong learning in tourism education. In D. Dredge, D. Airey \& M. J. Gross (Eds.), The Routledge Handbook of Tourism and Hospitality Education. London: Routledge. pp: 322-334.

Tribe, J., 2005. Overview of research. In D. Airey \& J. Tribe (Eds.) An international handbook of tourism education. Oxford: Elsevier. pp: 25-46. 
Tribe, J., 2005. Tourism, knowledge and the curriculum. An International Handbook of Tourism Education: 47-60. Available at: https://doi.org/10.1016/b978-0-08-044667-7.50007-0.

Veal, A.J., 2006. Research methods for leisure and tourism: A practical guide. Essex: Pearson Education.

Volgger, M. and H. Pechlaner, 2014. Interdisciplinarity, transdisciplinarity, and postdisciplinarity in tourism and hospitality education. In D. Dredge, D. Airey \& M. J. Gross (Eds.), The Routledge Handbook of Tourism and Hospitality Education. London: Routledge. pp: 85-102.

Wall, G. and A. Mathieson, 2006. Tourism: Change, impacts and opportunities. Essex: Pearson Education.

Wang, J., J. Huyton, X. Gao and H. Ayres, 2010. Evaluating undergraduate courses in tourism management: A comparison between Australia and China. Journal of Hospitality, Leisure, Sport and Tourism Education, 9(2): 46-62. Available at: https://doi.org/10.3794/johlste.92.258.

Views and opinions expressed in this article are the views and opinions of the author(s), Journal of Tourism Management Research shall not be responsible or answerable for any loss, damage or liability etc. caused in relation to/arising out of the use of the content. 